Acta Poetica 27 (1)

PRIMAVERA

2006

\title{
La risa y el humor. Apuntes para una poética histórica de la literatura mexicana
}

\author{
Martha Elena Munguía
}

El artículo plantea la existencia de dos vertientes en la historia literaria mexicana: una seria, sublime, elevada, que se identifica con los valores ideales y otra, expulsada a los márgenes, o bien ignorada, que tiene que ver con el humor y la risa. El trabajo se centra en la exploración de algunas de las formas en las que ha entrado el humor y la risa en la literatura seria, culta: la elección de una voz que cuenta la historia recuperando los tonos y las actitudes relativizantes, distanciados de la oralidad. La segunda forma que se analiza es la orquestación de los relatos a partir de la enunciación del caudillo, el jefe revolucionario, la autoridad, desde la parodia. Por último, se revisa la presencia de la figura del homosexual, como voz descentrada que ha permitido la introducción de lo jocoso y la burla en las formas literarias consagradas.

This article puts forward the existence of two mainstreams in Mexican literary history: one of them is serious, sublime and identified with ideal values; the other line, displaced to the margins or ignored, has to do with humour and laughter. The article explores some of the ways in which serious and cultured literature has admitted humour and laughter: the election of a voice narrating a story with relativistic tones and attitudes distanced from oral communication. The second way is the orchestration of stories taking as a point of departure the utterance of the caudillo, a revolutionary leader and the authority from the parody. Finally, the character of the homosexual is analyzed as a descentered voice that has permitted the introduction of the joke and the laughter in the canonical literary forms. 

Martha Elena Munguía

Universidad Veracruzana

\section{La risa y el humor. Apuntes para una poética histórica de la literatura mexicana}

A Pierrette, con quien tanto reíamos

La gravedad, la solemnidad, el sentimentalismo, el patetismo, parecen ser, en una mirada apresurada, los tonos predominantes en la literatura mexicana, las fuerzas articuladoras de las legítimas y más valiosas visiones ideales del mundo. Es como si a través de estos tonos se respondiera plenamente a las necesidades de elevación, sublimación, incluso heroización que suele pedírsele a la literatura. Con este sesgo se ha educado la apreciación artística de gran parte de las generaciones de lectores; a la vez, se ha promovido el mecanismo de identificación entre héroe y lector (condición ligada al patetismo y al sentimentalismo) y se ha ofrecido así un unitario ámbito elevado de reconocimiento para el amplio público, ávido de modelos ideales.

Esta vertiente ha sido, ciertamente, importante para el desarrollo de la literatura nacional; el problema es que críticos e historiadores la han considerado como la única legítima, la que representa y expresa la verdadera naturaleza de las vivencias artísticas de los mexicanos ${ }^{1} \mathrm{y}$, en esa medida, se han ex-

${ }^{1}$ Hablo aquí de los mexicanos, pero tampoco ignoro que mucho de lo que ha ocurrido en la tradición literaria de México y la forma en la que se ha estudiado, 
pulsado sistemáticamente los ecos del humor y de la risa en la conformación del lenguaje literario; la crítica ha ignorado otras vertientes, otras posibilidades expresivas en el arte verbal; y a tal grado esto ha sido así que, en general, tampoco se han considerado las huellas de la risa en los textos serios, canónicos. Las escasas veces en que se celebra el humorismo en algunas obras, éste es visto muy parcialmente, casi como recurso retórico, como un añadido a la totalidad de una composición supuestamente más compleja y significativa.

En 1901 Julio Guerrero publicó un estudio de psiquiatría social en el que intentaba explicar científicamente el fenómeno del crimen en México. Ahí apuntó una serie de observaciones acerca de la fisonomía y los rasgos morales y espirituales que delinean un perfil criminal, y las conclusiones a las que llegó se han repetido de todas las maneras posibles; las "verdades" que sentenció han marcado el desarrollo posterior del pensamiento sobre el ser y la cultura del mexicano. Hay ahí una afirmación que ahora me interesa retener porque concluye con mucha precisión una idea que se ha convertido en premisa, a veces silenciada, pero determinante, para estudiar y explicar las formas que adquieren las expresiones artísticas de México:

Cuando la atmósfera no está cargada, el espíritu se sosiega; pero la reacción es en sentido depresivo; y por eso el mexicano que no tiene alcohol, aunque no es triste por naturaleza, tiene largos accesos de melancolía; como lo prueba el tono espontáneamente elegiaco de sus poetas, desde Netzahualcoyotl, o el que firma las composiciones conocidas con su nombre, la serie inacabable de románticos en los tiempos modernos; y la música popular mexicana escrita en tono menor; esas danzas llenas de melancolía, que las bandas militares lanzan en los parques públicos a las brisas crepusculares, preñadas de suspiros y sollozos; y esas canciones populares que al son de la gui-

es compartido también por gran parte de los países latinoamericanos, por lo que valdría la pena hacer un estudio más abarcador. 
tarra, en las noches de luna se entonan en las casas de vecindad o por los gallos que recorren las avenidas. El medio en que habitamos suele transformar en tendencias melancólicas la gravedad del indio y la seriedad del castellano. En la Capital sin embargo, el uso del alcohol y otras causas que después estudiaré, a veces neutralizan este resultado, desarrollando un aticismo duro y malévolo que hace reír del prójimo; una filosofía semi-estoica y semi-burlona que hace desdeñar la vida y afrontar la muerte a puñaladas o balazos por cualquier chiste de banquete o párrafo de gacetilla (Guerrero, 23-24). ${ }^{2}$

Gravedad y seriedad resultan así los rasgos que nos legaron los ancestros y a esta herencia sanguínea viene a unirse la atmósfera en la que respiramos. No podíamos menos que tener un temperamento melancólico que va a engendrar expresiones de tono patético — crepuscular, también diría unos años más tarde Pedro Henríquez Ureña-. ${ }^{3}$ Raza y naturaleza unidas para definir la identidad nacional y su expresión artística. Las coordenadas han estado muy claras para concluir una valoración casi unánime sobre la literatura mexicana: es el arte verbal que responde a la gravedad, a la íntima tristeza, el único que ha podido ser considerado digno representante de un pueblo con esas características. En esta perspectiva, el humor, la

2 Es imposible no recordar en esta cita muchas de las afirmaciones de Octavio Paz en El laberinto de la soledad, lo que revela la fuerza de estas convicciones entre los intelectuales preocupados por entender y explicar el ser del mexicano: "La noche se puebla de canciones y aullidos. Los enamorados despiertan con orquestas a las muchachas. Hay diálogos y burlas de balcón a balcón, de acera a acera. Nadie habla en voz baja. Se arrojan los sombreros al aire [...] En ocasiones, es cierto, la alegría acaba mal: hay riñas, injurias, balazos, cuchilladas. También eso forma parte de la fiesta. Porque el mexicano no se divierte: quiere sobrepasarse, saltar el muro de soledad que el resto del año lo incomunica" (Paz, 184).

3 "Como los paisajes de la altiplanicie de la Nueva España, recortados y aguzados por la tenuidad del aire, aridecidos por la sequedad y el frío, se cubren, bajo los cielos de azul pálido, de tonos grises y amarillentos, así la poesía mexicana parece pedirles su tonalidad. La discreción, la sobria mesura, el sentimiento melancólico, crepuscular y otoñal, van concordes con este otoño perpetuo de las alturas [...]" (Henríquez, 235). 
risa, no son más que desviaciones inesperadas de un destino claramente trazado por la herencia sanguínea. De esta suerte, resulta que la risa de los mexicanos no puede ser sino una violencia que se hace a lo definitorio de su ser; de ahí que suela asociarse carcajada con gesto sombrío, burla, sarcasmo o de plano relajo. Es como si el buen humor del mexicano estuviera, en el fondo, preñado de oscuridad; no parece haber aquí lugar para la alegría o para la jovialidad. La risa es, así, una rasgadura en la dura máscara del diario vivir.

No es extraño, pues, que no se le haya prestado casi ninguna atención a las manifestaciones artísticas del humor en una cultura en la que sus intelectuales decidieron cerrar esa ventana porque estaba condenada de antemano. Si había humor en el arte mexicano éste tenía que ser agresivo, gris, mordiente, burlón, el pobre humor desteñido que producen las almas melancólicas. Lo más cercano a la risa que ha podido entrar al canon literario es la sátira, género de entre todos el menos festivo, el menos solidario por su decidida vocación moralista, por la posición de superioridad que adopta el satírico. Literatura que ríe para cumplir con su misión magisterial, de catecismo.

A los contundentes trazos con los que críticos e historiadores han desdibujado el perfil complejo y heterogéneo de la cultura mexicana unificándola y acallándole la diversidad, se une, por supuesto, la larguísima tradición occidental de desdén y desautorización de la risa en la vida y en el arte (es posible remontarse a la Biblia para desde ahí ir rastreando las huellas de esta actitud). ${ }^{4}$ Lo cómico no parece haber tenido nunca los mismos derechos que ha tenido lo trágico, lo lírico, lo épico o lo dramático. Lo cómico ha debido permanecer en los márgenes de la cultura letrada, porque reírse no es muy serio ni muy estético.

\footnotetext{
4 “Anda a la casa que está de duelo más que a la que está de fiesta: verás el fin de todo hombre, y al que vive le da para pensar. Más vale el pesar que la risa: la tristeza en el rostro promete un mejor corazón. La casa en duelo da para pensar a los sabios, los tontos no piensan más que en la casa alegre" (Eclesiastés, VII, 2-4).
} 
Hay otro punto en estas consideraciones que no quiero perder de vista: nadie parece haber tenido dificultades para distinguir entre lo trágico en la vida y lo trágico en el arte; lo heroico en el acontecer de una vida y la heroización en un texto ficcional. Pero parece muy difícil el esfuerzo de distinguir entre la risa en la vida y la risa en el texto literario; ${ }^{5}$ y si afirmo esto es porque no es nada común encontrar tratados sobre la risa artística, mientras que sí abundan los estudios sobre la risa como acto fisiológico, como manifestación psíquica o como expresión ética. También es considerable lo que se ha escrito alrededor de los efectos sociales de la risa y esto ya no es ajeno al problema de la estética: la risa no enciende hogueras, decía Bajtín, no crea dogmas; sin embargo, apunta Averintsev, en seria polémica con esta versión innegable pero parcial de la risa, que "[...] cuando una hoguera ya aparece edificada, a su lado no pocas veces suena la risa, formando parte del plan inquisitorial" (Averinstsev, 25). Si la risa es solidaria y liberadora, no es menos cierto que puede ser un arma para sembrar el terror y la violencia; también existe, dice Averintsev, "la risa cínica, la risa grosera, en cuyo acto el riente se despoja de la vergüenza, de la piedad, de la conciencia" (21). Entonces, es importante no perder de vista la existencia de diversos tonos y orientaciones de la risa social, porque éstos también entran en el trabajo artístico que de ella se haga. ${ }^{6}$ Detrás de la risa puede acechar la garra del llanto, puede estar la alegre burla del que desenmascara verdades oficiales o la autoironía mordaz.

${ }^{5} \mathrm{Y}$ en esto se halla una semejanza entre la risa y el fenómeno de lo lírico que ha sido percibido, en su manifestación artística, como una expresión perfectamente correspondiente, encarnada, de una herida en el alma del poeta.

${ }^{6}$ Es muy pertinente la revisión que hace Tatiana Bubnova de la recepción problemática que ha tenido la propuesta histórica, contextualizada, de Bajtín, que, en sus estudios, veía el carnaval como el resultado de la cultura popular de la risa y, por otra, la utilización que se ha hecho de la noción de carnaval como una herramienta teórica transhistórica. Algunos estudiosos se han ensañado con las posibles contradicciones de Bajtín en el seno de su teoría de una ética responsable y la terrible realidad que podía resultar de su visión del carnaval popular (Bubnova, 417-431). 
Ahora bien, para desbrozar el camino hacia la ubicación de la risa en tanto particular visión estética, es preciso atender, más que a su forma externa, a lo que construye porque, sin duda, una risa trágica no va a engendrar hilaridad, humor, ni propondrá, en tanto acto jubiloso, una imagen despreocupada o liberadora de la vida. Otro tipo de risa podrá generar el desprecio hacia los vicios y bajezas de los pueblos que desvirtúan los "verdaderos" valores de la vida. Para los estudios literarios que buscan recuperar la perspectiva histórica, es importante no limitarse a seguir bordando sobre las manifestaciones serias, jerárquicas, elevadas de la risa oficial —la seriedad en sus diversas expresiones ya ha sido muy atendida-, sino volver la atención hacia la risa que engendra la liberación del espíritu y la agudización del sentido crítico. Luis Beltrán, en su muy sugerente propuesta de repensar la historia literaria occidental a partir de la oposición entre risa y seriedad, como las grandes directrices artísticas que han marcado el desarrollo de géneros y vertientes poéticas, formula este problema que debe encarar la crítica literaria, reconociéndole dos dimensiones y dos orientaciones a la risa: una popular y otra jerárquica, culta:

La risa popular expresa la continuidad del espíritu de las tradiciones, en forma de rechazo de las miserias de la desigualdad que ha impuesto la historia y de oposición al mundo cultural serio, que legitima esa desigualdad. La risa jerárquica representa un fenómeno en apariencia contrario. Se trata de la reprobación de lo que no se somete a la jerarquía civilizatoria. Esta risa suele contemplar la desigualdad con distintos acentos, que van desde la denuncia de la falsedad de lo serio y oficial hasta la reprobación de lo bajo como dominio del vicio (Beltrán 21).

Si ya se ha reconocido la expresión de la risa jerárquica en tanto portadora de las visiones oficiales del mundo, y por tanto disfraz de la seriedad y la adustez, es preciso trabajar en la 
tarea de reubicar la risa que Luis Beltrán, siguiendo a Bajtín, llama popular, en el plano de lo artístico o más específicamente, de lo literario.

¿Podríamos hablar de géneros propiamente cómicos o humorísticos o rientes? ¿Serán la comedia, la farsa, la sátira, los géneros donde vive más plenamente la risa artística? ¿Qué forma literaria le es connatural? Me parece que es posible apreciar de primer vistazo que no pueden ir por el deslinde genérico las preguntas que ayuden a formular con precisión el problema. Son callejones sin salida o, en el mejor de los casos, respuestas muy parciales. La ironía, por ejemplo, ha sido una de las formas de la risa artística más estudiada. A veces se le ha visto como rasgo puramente lingüístico, como actitud ante el otro y su discurso, pero ha faltado analizarla inscrita en el amplio contexto de la risa como visión estética. Caso similar es el de la parodia.

Para replantear más provechosamente las preguntas puede resultar útil volver a la propuesta de Bajtín:

La risa es una actitud estética hacia la realidad, definida pero intraducible al lenguaje de la lógica; es decir, es una determinada forma de la visión artística y de la cognición de la realidad y representa, por consiguiente, una determinada manera de estructurar la imagen artística, el argumento y el género (1986, 231).

Vista así, la risa constituye un punto de aprehensión artística de la vida en la medida en que es una forma específica de apropiarse de un conocimiento de la realidad e implica, de entrada, una valoración ética del mundo en el que está inmersa; la risa literaria conforma la fuerza de organización de las múltiples facetas de la vida, les da sentido, cohesión, unidad y armonía en la composición textual. Por esto, y todavía siguiendo a Bajtín, sería necesario pensar la risa como una de las fundamentales for- 
mas arquitectónicas, en tanto que éstas abrigan valores cognitivos y éticos, encarnan la expresión de la relación valorativa del autor y del observador con algo que está fuera de la materia en la que vive (Bajtín 1989, 25-27).

Cada forma arquitectónica cobra vida en diversos materiales (el sonido, el color, la palabra, etc.), de ahí los diferentes tipos de arte que pueden compartir la expresión espiritual de lo cómico, lo trágico, lo dramático. Además, las formas arquitectónicas se realizan a través de distintos procedimientos compositivos: diálogos, dramas, relatos, versos, etc. Por esta razón es posible encontrar la tonalidad de la risa en los diálogos novelescos, en la narración de un transmisor oral de cuentos tradicionales, incluso en un poema que se expresa en las formas rítmicas y métricas de un soneto o un romance. La risa como actitud ante la vida, ahí, presidiendo la orquestación de un todo novelesco, afinando las cuerdas de la lira para un canto. Así, salimos de la limitación de equiparar la risa a lo alegre, a lo chistoso o de asociarla con lo satánico, la pérdida de Dios, la antigua caída, o la pena disfrazada; pero, sobre todo, se elimina de una vez por todas la tentación de ubicarla en el plano de los tropos o de los recursos retóricos y se gana la posibilidad de reconocerla en tanto plena fuerza articuladora de una perspectiva especial para estetizar el mundo.

Desde este punto de vista puede quedar más claro que la risa es un fenómeno multifacético, complejo, ligado a la heteroglosia, con una infinita capacidad de transmutación, de voces y acentos. En todo caso, resulta una de las formas privilegiadas para introducir en el arte verbal, en cualquier género literario, la ambigüedad, la pugna, la inestabilidad de las certezas, para penetrar en las voces autorizadas, consagradas, reorientando los sentidos pretendidamente unívocos. La risa siembra la duda, puede funcionar como un eco distorsionador de lo que tiene valor único y lineal, y ha sido, sobre todo, una increíble fuente generadora de imágenes artísticas, aunque po- 
cas veces se le haya reconocido esta rica aportación en las historias literarias nacionales. Después de los trabajos de Bajtín sobre la tradición carnavalesca y los lenguajes carnavalizados en la literatura europea, nadie puede negar la importancia que para el desarrollo de la novela tuvieron, por ejemplo, las figuras del pícaro, el bufón y el tonto.

El problema es que para explicar la propia tradición literaria latinoamericana, hemos seguido importando estos hallazgos - el carnaval, sobre todo-, tan pertinentes para estudiar la narrativa europea, pero poco nos hemos detenido a pensar en la peculiaridad de nuestros procesos culturales, incluso en las resonancias múltiples y diversas que puede tener la risa en nuestras sociedades. Menos nos hemos preocupado por entender las distintas formas en las que los escritores han trabajado estas resonancias. Hay que detectar la orientación que ha tenido la literatura por la presencia de los ecos de la risa. Es menestar analizar qué imágenes artísticas se han gestado en las literaturas latinoamericanas, cómo ha penetrado la risa en los lenguajes literarios canonizados y qué capacidad ha tenido para reorientarlos y darles un giro a los trayectos por los que ha corrido la historia literaria. Sólo explicando estos procesos, estaremos en condiciones de explicar cuáles han sido las fuentes más productivas de la risa para la composición de los distintos géneros literarios; en qué momentos se ha reído más y con qué tipo de risa. Un sinfín de preguntas puede hilvanarse que casi no ha tenido respuestas.

Una de las puertas de entrada al estudio del problema tiene que ser, forzosamente, el de la oralidad, dado que la risa constituye uno de los nexos privilegiados que vinculan la cultura letrada con la cultura oral tradicional y por esta relación se ha constituido en una fuerza que ha empujado el desarrollo y la transformación de los géneros literarios. La importancia que le concedo a este aspecto de la oralidad en la tradición literaria culta obedece, por una parte, a la premisa teórica de que la 
risa plena, profunda y generadora de imágenes artísticas se ha gestado en la cultura popular, y, por otra, a que en el caso particular de México y América Latina, la oralidad constituye, todavía en nuestros días, una de las formas privilegiadas de comunicación, de recreación y transmisión de saberes, de imaginación y, por tanto, es una de las principales fuentes alimentadoras de la creación literaria culta, lo que puede apreciarse, en primera instancia, en la frecuente recreación poética de las hablas rurales o marginales, en la constante apelación a la figura de los contadores orales para construir cuentos y novelas en este continente.

Entonces, más que pensar en una figura relativamente estable que encarne la risa desenmascaradora, como la del bufón, del pícaro, del tonto o de la cortesana, ${ }^{7}$ habría que revisar el papel del contador oral de cuentos, de origen pueblerino que busca contar su versión de los hechos ante un auditorio dispuesto a reírse y a desconfiar. Tal vez podamos dar con una de las claves en la frecuente elección que hacen los escritores de una figura que para contar se escuda tras la coartada de que no es su punto de vista, individual, sino que solamente transmite lo que se dice, lo que se murmura.

Ha habido en todas las épocas de nuestra historia una ingente producción que podríamos llamar media, a caballo entre lo popular y lo culto, que ha cobrado forma y expresión en la escritura, pero que revela la presencia del ingenio oral, espontáneo, colectivo; y estas manifestaciones han permanecido en los márgenes de la cultura alta por sus mismos rasgos: la falta de pretensiones artísticas, la coyuntura inmediata a la que responden. Pero sin estos productos no es posible entender del todo el desarrollo de la literatura mexicana: me refiero a los

\footnotetext{
${ }^{7}$ Los pícaros de nuestra tradición literaria han sido más moralistas que festivos; no existe la fuerte tradición del bufón en nuestra cultura; los tontos literarios no han tenido la sagacidad para desenmascarar nada y nuestras cortesanas son prostitutas tristes, sin voz, que se anegan en el fango de su perdición.
} 
multiformes géneros paródicos que ingenios anónimos han hecho de poemas cultos, de mitos nacionales. En cantares de muy diversos géneros el devoto pueblo mexicano se ha reído de las cosas santas; ha celebrado jocosamente el placer de la carne; ha criticado agudamente el ejercicio del poder, ha exaltado la bebida y ha enfrentado el ineludible hecho de la muerte, siempre inminente, siempre amenazante. ${ }^{8} \mathrm{Si}$ bien gran parte de esta vida cultural de México ha permanecido intocada, ignota para los intelectuales si no es como curiosidad folclorizante, no ha sido menos importante y vital en la conformación de nuestro ser nacional, en el desarrollo de nuestra literatura.

En folletos, en periódicos humorísticos — abundaron, recuérdese, en el siglo XIx: La orquesta, La tarántula, El Padre Cobos, El Boquiflojo, El Embudo y Las Tijeras, El sable de Papá, El Torito, Cascabel, La Linterna, La Paparrucha, El Coyote, El Ahuizote, El Hijo del Ahuizote, con nietos y bisnietos que proliferaron, entre muchos otros-, en las actas judiciales de la inquisición, en los muros de las grandes ciudades han vivido jocosas, apresuradas y frecuentemente mal compuestas, respuestas literarias a la seriedad y a la supuesta alta moralidad de autoridades civiles y religiosas. Con declarada repulsión, pero secreta atracción, algunos cronistas, historiadores, inquisidores o escritores han sabido dejar constancia de algunas muestras de este ingenio que se revuelve contra el poder, por ejemplo ésta contra Antonio López de Santa Anna:

\author{
Es Santa sin ser mujer \\ es rey sin cetro real \\ es hombre mas no cabal \\ y sultán al parecer
}

\footnotetext{
${ }^{8}$ Se ha dado por sentado que esta actitud hacia la muerte es exclusiva y caracterizadora de los mexicanos; se repite por propios y extraños el prejuicio como si fuese una verdad seriamente contrastada con las manifestaciones populares de otras sociedades.
} 
que vive debemos creer

parte en el sepulcro está

y parte dándonos guerra

¿Si será esto de la tierra

o qué demonios será?

(cit. en Torres, 334-335).

La parodia de los textos poéticos más graves y elevados de nuestra canónica tradición literaria tiene un fuerte arraigo popular. Es fácil constatar cómo casi cada poema consagrado, en los que bebió la sensibilidad del pueblo mexicano, ha recibido su parodización festiva y anónima, y no me estoy refiriendo a la extendida práctica de la elaboración de parodias literarias, sino de respuestas casi espontáneas y lúdicas que da la gente a poemas serios, a canciones solemnes: "Pues bien, yo necesito / decirte que ando crudo, / que no traigo dinero; / que es mucho lo que sudo, / que es mucho lo que 1loro / sin que el cruel cantinero / se apiade algo de mí"; o bien: "Si a tu ventana llega un burro flaco / trátalo con respeto que es tu retrato".

Los escritores han debido hacer referencia a este vasto mundo de la vida popular y sus manifestaciones orales, bien para negarlo, bien para satirizarlo, zaherir la vulgaridad, el mal gusto y elevar el nivel de incultura de este pueblo analfabeta. Pero en algunos casos, se ha usado como base, como fuente, invisible a veces, pero ahí latente, para construir una literatura dinámica, vital, que ha renovado las posibilidades expresivas de los géneros fijos y canonizados. En este sentido, puede trazarse la larga trayectoria que ha tenido la escritura que se enlaza a la risa popular, una escritura que se ha forjado a través del lente a veces mordaz, a veces cínico, a veces irónico, a veces festivo, que da la risa.

Para explicar estas afirmaciones puedo aludir a dos textos ubicados en la aurora de la conformación de lo que mucho 
después sería la nación mexicana, dos textos que sin duda pasarían a integrarse a la memoria de la tradición literaria, a la memoria de los géneros que propiciaban, sin siquiera proponérselo: por un lado tenemos Las cartas de relación que Hernán Cortés enviaba a los monarcas de la Península, cartas que sin duda marcaron un camino de escritura con su total ausencia de risa: Cortés estaba intentando legitimar sus hazañas y configurar su propia imagen como la de un héroe católico, leal vasallo y esforzado guerrero en un mundo bárbaro, ajeno a esos valores absolutos. Por ello destierra de su escritura cualquier asomo de otra voz, cualquier duda, cualquier vacilación. Si bien su tono apologético implica un diálogo tenso con las voces detractoras e injuriosas que se levantaban contra él, Cortés se las arregla para ser directo, hablar con su Señor, un yo ante otro yo imponente, nada más; no quiere dejar huellas de la presencia de esas otras voces, su escritura está empeñada en borrar los ecos de las diatribas. Esta intención no puede contener humor ni asomos de risa.

Frente a los tonos graves y solemnes que levanta Cortés para justificar y legitimar sus acciones, Bernal Díaz del Castillo ofrece otra visión, no necesariamente deliberada, pero sí inevitablemente polémica con la del primero y - lo que ahora me interesa resaltar - en su reconstrucción histórica, postulada como verdadera, escuchamos los ecos de la risa popular:

Oí decir que le solían guisar carnes de muchachos de poca edad [a Moctezuma] y, como tenía tantas diversidades de guisados y de tantas cosas, no lo echábamos de ver si era carne humana o de otras cosas, porque cotidianamente le guisaban gallinas, gallos de papada, faisanes, perdices de la tierra, codornices, patos mansos y bravos, venado, puerco de la tierra, pajaritos de caña, y palomas y liebres y conejos, y muchas maneras de aves y cosas que se crían en esta tierra, que son tantas que no acabaré de nombrar tan presto. Y así no miramos en ello; mas sé que ciertamente desde que nuestro capitán le reprendía el sacrificio y 
comer de carne humana, que desde entonces mandó que no le guisaran tal manjar (Díaz, 166).

Obsérvese cómo desde estas primeras historias la voz popular, el murmullo social, se va fundiendo con los afanes de dar cuenta, de reconstruir y de postular la verdad. Ya están aquí los atisbos de un hablar en varias voces, donde entran los acentos orales y la visión humorística de los hechos. La risa no suena aquí abiertamente, pero puede apreciarse el gesto malicioso, casi de sonrisa con el que Bernal Díaz está construyendo la imagen del "Gran Moctezuma". Esta actitud hacia la verdad, hacia la historia y esta elección narrativa marcará caminos al desarrollo del relato y es esto lo que hace falta indagar: cómo se van conformando estas voces, cómo se suele cruzar en la enunciación culta, escrita, el acento y la visión de lo oral y cómo es esta forma de articular la enunciación, en una sonrisa apenas aflorada, la que va contribuyendo a forjar posibilidades expresivas para la narración, imágenes artísticas.

Quiero aclarar que no postulo que la relación entre el desarrollo posterior de la literatura mexicana y estos textos augurales sea mecánica, inmediata. Tal vez, muchos escritores ni siquiera se reconocerían como herederos de estas crónicas y cartas de conquista. Pero es preciso entender que estas formas composicionales se van sedimentando en la cultura, en la tradición literaria y van dejando su impronta en la conformación de los discursos artísticos, en tanto que se van constituyendo como opciones narrativas, opciones para crear imágenes artísticas.

Siglos después podemos encontrar una escritura como la de Juan José Arreola, inscrita en esta vertiente narrativa, que configura los discursos dejando que entren en la escritura diversas voces, tonos y acentos que aportan una mirada jocosa, con la capacidad de relativizar las supuestas verdades únicas, llegando incluso a renunciar a la convención de un narrador fuerte, privilegiado, que centralice la enunciación: 
Fray Juan era buena gente y andaba de aquí para allá vestido de franciscano, con la ropa hecha garras, levantando cruces y capillitas. Vio que nos gustaba mucho danzar y cantar, y mandó traer a Juan Montes para que nos enseñara la música. Nos quiso mucho a nosotros los de Tlayolan. Pero le fue mal y dizque lo mataron. Dicen que aquí, dicen que allá. Si fue en Tuxpan, lo hicieron cuachala. Si fue aquí, nos lo comimos en pozole. Mentiras. Lo mataron en Cíbola a flechazos. Sea por Dios (Arreola, 7).

En esta voz puede apreciarse cómo el humor es el elemento clave para recuperar el pasado y volver a contarlo; así, la historia se vuelve antisolemne, se le desnuda de la gravedad. El encargado de contar este fragmento no es un intelectual que escriba, es un contador oral, que habla, incluso, a nombre de su pueblo. Y no es que podamos relacionar directamente esta prosa con la escritura de Bernal Díaz. Sin embargo, se trata de que éste forjó un modo de penetración en la realidad histórica, modo que fue fermentando como posibilidad expresiva, y que muchos años después puede alcanzar concreción artística en la elaboración de este lenguaje poético de Juan José Arreola, preñado de acentos y voces populares.

No es otra cosa el trabajo artístico de Juan Rulfo, también inscrito en esta rica y vasta vertiente de literatura construida a través del lente de la risa, aunque mucho se haya insistido en la visión negra y pesimista que campea en su narrativa. Sí, seguramente hay mucho de oscuridad en esta breve y densa obra, pero no puede olvidarse que detrás de este lenguaje popular, poética invención de Rulfo, anida siempre una risa mordaz, a veces irónica, a veces maligna, punzante, a veces también alegre y relativizadora como en "El día del derrumbe", aguda parodia del habla huera y rimbombante de los políticos mexicanos.

En estos escritores cristalizan los viejos intentos de construir la figura del contador oral como punto de enunciación privilegiado para articular una historia que lleva el peso, el 
acento, de la visión popular — recuérdense todos los esfuerzos de los escritores costumbristas, indigenistas y de la novela de la Revolución, empeñados en lograr darle voz y vida a los sectores populares, aunque solían quedarse a mitad del camino, recuperando las formas externas de estas voces-. Y en esta opción narrativa se ha logrado forjar la imagen poética de un hablar campesino, rural o marginado en la urbe, que desafía, que se burla, que desestabiliza las versiones oficiales y que se caracteriza, fundamentalmente, por un hablar con un dejo de sonrisa detrás.

Pero ha habido otra vía en nuestra historia literaria para introducir la risa en la escritura; otra vía que no es menos importante y sí muy significativa de nuestros procesos sociales y culturales: Jorge Ibargüengoitia no acudió a la figura tradicional del que mira desde fuera y no comprende, pero tampoco se decidió a trabajar con la imagen del contador oral pueblerino; opta por dar la voz al propio caudillo revolucionario para reírse y desenmascarar las trampas discursivas, las mañas desarrolladas por los nuevos vencedores para medrar, para enriquecerse y para seguir aparentando que se siguen defendiendo las sagradas causas populares: "En este capítulo voy a revelar la manera en que la pérfida y caprichosa Fortuna me asestó el segundo mandoble de ese día, fatídico, por cierto, no sólo para mi carrera militar, sino para mi Patria tan querida, por la que con gusto he pasado tantos sinsabores y desvelos: México" (Ibargüengoitia, 17), dice el revolucionario de Los relámpagos de agosto. Dado que en este país han sido los dirigentes revolucionarios, los jerarcas, los que han tomado la palabra para dar su versión de los hechos, es preciso que el desenmascaramiento se opere desde el interior de esas mismas voces; así resulta más eficaz el ridículo que busca ponerse en evidencia. Ibargüengoitia devela en sus parodias la soberbia y la arrogancia con que han escrito profusamente sus memorias los caudillos, los hombres de poder, asumiendo que sus vidas son 
trascendentes y que para entender los caminos del país, es preciso entender la dirección de sus vidas. ${ }^{9}$

Ibargüengoitia no es el único caso que trabaje de esta manera la risa literaria; es heredero de una larga aunque sinuosa y a veces desdibujada tradición paródica de la voz y la versión oficial de los hechos — no se olvide, por ejemplo, la risueña actitud con que se componían las llamadas "tradiciones", género inventado por Ricardo Palma, pero muy fructífero en algunos países latinoamericanos- Se ha reflexionado mucho sobre la novela histórica en México y la crítica se ha preguntado el por qué de esta compulsión historicista de la literatura nacional pero no siempre se ha hecho análisis de la respuesta jocosa que da esta tradición al acartonado recuento de los hechos y a las francas tergiversaciones o silenciamientos que con tanta frecuencia ha hecho la historia oficial. La risa suele ser una de las armas con las que se emprende esta reconstrucción paralela y, por eso, la efectividad y la riqueza del género. Fernando del Paso escribió una obra monumental para volver a contar la historia del imperio de Maximiliano, y en ella abundan los ecos de la risa y de la antisolemnidad. Del Paso aprovecha la figura de la loca, Carlota la emperatriz, para dar la voz a una versión interior, pero antioficial de los hechos, y la locura posibilita el juego, la injuria, la burla de la propia figura del emperador fracasado, un personaje simbólico en la historia de México, pero pocas veces iluminado con la luz de la familiaridad y del irrespeto burlesco:

${ }^{9}$ Debo aclarar que tanto la obra de Rulfo como la de Ibargüengoitia sí han sido estudiadas tomando en cuenta el humor irónico que campea en ellas, lo cual indica que la crítica ha reconocido la fuerza y la importancia de la risa en la composición artística de algunos textos, pero no se ha trabajado teóricamente el problema, ni ha sido estudiado desde el punto de vista histórico, que es lo que estoy proponiendo aquí. Las críticas que se han orientado en esta dirección - pienso, por ejemplo, en el trabajo de Ana Rosa Domenella (1989) sobre la obra de Ibargüengoitia - sin duda aportan elementos imprescindibles para emprender la labor historiográfica y teórica. 
[...] por qué cuando estabas ya frente al pelotón y pediste que no se derramara más sangre en México después de la tuya y la de tus dos generales, por qué dime, Maximiliano, después de que gritaste Viva México y unos segundos antes de la descarga, y por tonto y por débil, por crédulo, por cándido, por confiado, por arrogante y holgazán, por temerario y por falso, por imbécil, dime, por qué no te condecoraste tú mismo con el gran collar de la Orden Suprema del Gran Pendejo? (Paso, $613)$.

Es también la parodia uno de los caminos privilegiados para romper con el ensimismamiento y el sentimentalismo que ha definido el trayecto de la lírica; no sólo los ingenios populares han parodiado los graves textos del santuario lírico nacional; desde la propia tradición culta se han minado los cimientos en los que se asienta la solemnidad de una lírica que se desgastó en la abusiva recurrencia a la emotividad. El poeta mexicano Abigael Bohórquez fue un hábil re-escribidor de poemas líricos consagrados, utilizándolos lúdicamente para cantar el amor homosexual, que esa tradición poética con tanta frecuencia disimulaba o negaba:

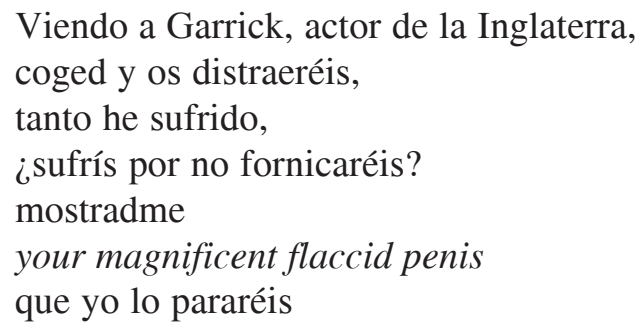

(Bohórquez, 180). ${ }^{10}$

Así, de haber tenido siempre un solo tono, una sola orientación ética, la del hombre que le canta a la mujer, invariable-

10 Recuérdese el subtexto de este poema, "Reír llorando" de Juan de Dios Peza, una de las composiciones patéticas más populares del siglo xx en México. 
mente objeto del deseo masculino, Abigael Bohórquez acude a las formas y lugares comunes esclerotizados en el patetismo y los vuelve juego, provocación, al imprimirle una radical reorientación, al proponer una ética y una estética que atenta contra los altos valores, contra el buen gusto, contra el silencio y la invisibilidad del erotismo homosexual. La reescritura de Bohórquez pone en crisis la función que la sociedad le ha exigido tradicionalmente a la poesía: cantar sentimientos elevados negando el impulso sexual al sublimarlo en la abundancia de lágrimas vertidas.

La obra poética de Abigael Bohórquez no sólo se funda en la parodización de poemas consagrados, sino que apela también a formas lingüísticas, bien reconocidas socialmente, por ejemplo, las del medievo, las del barroco e, incluso, del mundo náhuatl, para proponer nuevas visiones del amor y de las relaciones humanas, en un agudo travestismo provocador:

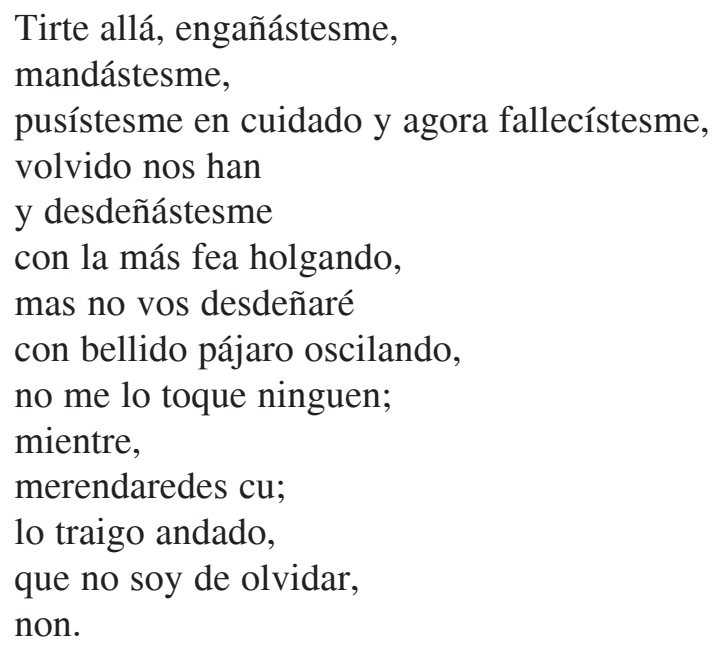

(Bohórquez, 192).

La vivencia de lo sexual se despoja así de los velos con los que se ha solido cubrir; las partes ocultas del cuerpo vuelven a 
ser mencionables y adquieren la dignidad poética de la que siempre se les ha privado. Es posible reír del deseo, del engaño, del abandono, del placer y, sobre todo, es legítimo familiarizar en el juego los moldes poéticos tradicionales. Esta estética postula nuevas formas de relación con la tradición literaria al incorporarla dinámicamente y actualizarla con humor.

Si bien he apelado a la referencia de un poeta poco conocido en las letras nacionales y por tanto poco estudiado, no por ello resulta menos significativa y de trascendencia la propuesta estética de Abigael Bohórquez. Por otra parte, su evocación me abre las puertas a la posibilidad de plantear que la voz articulada desde la homosexualidad, reconocida y afirmada en cuanto tal, pudiera constituir una de las construcciones artísticas más consolidadas en nuestra tradición literaria, por donde ha entrado el humor, la risa, la mirada desestabilizadora, relativizadora y desenmascaradora. El homosexual que no había accedido a la palabra, si no era como voz controlada por las voces dominantes que lo veían con extrañeza, que había permanecido en los márgenes de lo establecido como visible, ha acumulado un nutrido repertorio de formas alternativas para relacionarse con el lenguaje, para jugar, para torcerlo, para obligarlo a servir a otros fines expresivos, distintos de los autorizados. La propia imagen del homosexual se ha ido convirtiendo en una de las figuras privilegiadas para introducir en la lírica y en la narrativa las caracajadas sonoras que no habían estremecido los ritmos habituales.

La mirada descentrada del amor parece brindar la ocasión de desmontar los prejuicios, las mentiras, los silenciamientos de discursos consagrados a un solo modo de amar, a un solo tipo de belleza — la femenina vista con lentes masculinos-. El homosexual ha debido apelar a la tradición sólida de estos discursos, pero se ha visto impelido a jugar con ellos, a empujar hacia las fronteras de sus posibilidades expresivas los tropos e imágenes convencionales. No se pierda de vista que no estoy 
hablando de esto en términos temáticos, sino que lo retomo en la medida en que tiene que ver con el problema de la poética, pues estoy explorando los modos de la enunciación; así, las inflexiones del homosexual se han vuelto lugar ideológico del discurso, punto de aprehensión estética. Entonces, el homosexual e incluso el travestido, parecen erigirse en figuras a veces grotescas, a veces sórdidas, que lanzan el grito desgarrado, pero también en figuras capaces de articular la parodia, de resistir la opresión y el escarnio y encarnar la subversión, de decir manieristamente pero también con risa, lo que aman.

El hombre amanerado ha resultado tradicionalmente un personaje frecuente en los chistes populares y ha sido en la historia de la cultura siempre objeto de discurso. Esa marginalización lo ha hecho, en el siglo xx, un sujeto que, en principio, desconfía de las instituciones establecidas, se relaciona críticamente con los valores morales implícitos en un lenguaje asumido, en general, como neutro, sin matices sexistas; este personaje se vuelve sujeto, ahora toma la palabra, reta, se vale de la risa para evidenciar el prejuicio, la mendacidad de un machismo que ha sido castrador. Así se propone otro universo posible para estetizar el amor y el cuerpo masculino, y en este trabajo artístico la risa es el punto de partida para la voz y para la perspectiva desde donde se aprehende el mundo:

Juguemos al pendejo, vida mía; verás qué divertido, cuando a huevo tienes que celebrar el año nuevo con sonetos y muecas de alegría [...]

Acaso te amanezca alborotada - otrora erecta, dura y agresivala dulce prenda, por mi mal hallada.

(Novo, 389). 
Acaso por esta historia de marginalización el homosexual sea una figura con capacidad de autosarcasmo. Lo que es real, es que pocas veces en la historia literaria de México se había hablado con tal desenvoltura de los genitales masculinos; pocas veces habían entrado a la lírica las palabras consideradas groseras y esta libertad abrió espacios de expresión menos graves y solemnes.

Y a todo esto se podrá argumentar que no puede resultar más que extraño o inverosímil el hecho de que en países latinoamericanos que arrastran una historia ancestral de injusticias, que tienen amplios núcleos de población marginados, no hayan encontrado los escritores el modo de trabajar esas voces y hacer que entren con sus visiones y sus risas en los textos literarios. Y es que la marginalización del indio, por ejemplo o de la mujer, ha sido tan aguda, tan ancestral que se les ha negado la palabra sistemáticamente; ni siquiera se ha buscado entender sus horizontes emotivos, valorativos, ni al menos parece haberse asumido que posean una mirada particular, estetizadora del mundo y de la vida. Simple y sencillamente se les ha hecho objeto de discurso y, en esa medida, se les ha construido como imágenes patéticas, más o menos fijas que no pueden portar ecos de risa para que impulsen el desarrollo y la transformación de los géneros literarios.

Las mujeres muy recientemente han ido, en tanto tales, tomando la palabra. Asistimos al proceso de construcción de las propias inflexiones porque ha debido pasar una gran parte del tiempo en esta búsqueda de la voz propia. Los indios todavía no toman la palabra literaria que constituya un puente de comunicación con la cultura mestiza a la que resisten y que los amenaza con singular ferocidad. Seguramente por estas razones siguen siendo las grandes ausencias discursivas en la literatura nacional mexicana y sólo aparecen como temas, como problemas de justicia, de educación, de distribución de la riqueza. 
Hasta aquí he logrado reconocer solamente unas cuantas figuras artísticas generadas por la vertiente literaria del humor en México: la del relator oral de cuentos, la del caudillo o jefe revolucionario que rememora sus hazañas y la del homosexual. Estas figuras, bastante consolidadas en nuestra tradición literaria, han sido construidas con voz propia y se han caracterizado por retar las versiones oficiales, practican el autoescarnio, la parodia y la risa festiva. Atraviesan la historia literaria y están presentes en distintos géneros literarios. Se podría afirmar que han conformado líneas poéticas de desarrollo de los géneros y que es todavía muy precariamente como se les ha estudiado. Debe de haber más figuras que encarnen la risa y la desacralización literaria, pero hace falta hacer un recorrido más exhaustivo y detenido para entender las diversas modalidades que han adquirido y la transformación de los proyectos estéticos que han propiciado. Una de las fuentes para lograr esta reconstrucción es la literatura oral y la literatura que ha vivido en los márgenes de la alta cultura, porque estas manifestaciones han sido mucho más importantes de lo que se ha reconocido, en el proceso de forjar la literatura nacional.

\section{Bibliografía}

Arreola, Juan José, La feria, México, Joaquín Mortiz, 1974.

Averintsev, S., "Bajtín, la risa, la cultura cristiana", en AA.VV., En torno a la cultura popular de la risa, Tatiana Bubnova (ed.), México, Anthropos-Fundación Cultural Eduardo Cohen, 2002. Bajtín, Mijail, Problemas de la poética de Dostoievsky, trad. Tatiana Bubnova, México, Fondo de Cultura Económica, 1986.

—, "El problema del contenido, el material y la forma en la creación literaria”, en Teoría y estética de la novela, trad. Helena S. Kriúkova y Vicente Cazcarra, Madrid, Taurus, 1989, pp. 13-75. Beltrán Almería, Luis, La imaginación literaria. La seriedad y la risa en la literatura occidental, Madrid, Montesinos, 2002. 
Bohórquez, Abigael, Poesía en limpio. 1979-1989, Hermosillo, Universidad de Sonora, 1990.

Bubnova, Tatiana, "Fiesta, ruptura y transgresión según Bajtín”, en Lenguajes de la tradición popular. Fiesta, canto, música y representación, Yvette Jiménez de Báez (ed.), México, El Colegio de México, 2002, pp. 417-431.

Díaz del CAstillo, Bernal, Historia verdadera de la conquista de la Nueva España, México, Porrúa, 1998.

Domenella, Ana Rosa, Jorge Ibargüengoitia. La transgresión por la ironía, México, UAM, 1989.

Guerrero, Julio, La génesis del crimen en México. Estudio de psiquiatría social, París-México, Librería de la Vda. de Ch. Bouret, 1901.

Henríquez Ureña, Pedro, “Don Juan Ruiz de Alarcón”, en Ensayos, José Luis Abellán, Ana María Barrenechea (eds.), México, Archivos, 1998, pp. 235-245.

IbARGÜEngoItiA, Jorge, Los relámpagos de agosto, México, Joaquín Mortiz, 1992.

Novo, Salvador, Antología personal (poesía, 1915-1974), México, Conaculta, 1991 (Lecturas Mexicanas 37, tercera serie).

Paso, Fernando del, Noticias del Imperio, México, Diana, 1997.

PAz, Octavio, El laberinto de la soledad, Enrico Mario Santí (ed.), Madrid, Cátedra, 6 ${ }^{a}$ ed., 2001.

Torres, Teodoro, El humorismo y la sátira en México, México, Editora Mexicana, 1943. 